\title{
PERANAN PESANTREN DALAM TATANAN GLOBAL
}

\author{
Oleh : Zuman Malaka ${ }^{1}$ \\ zuman_mlk@yahoo.co.id \\ STAI TARUNA Surabaya
}

\begin{abstract}
Abstrak : Lembaga pendidikan pesantren merupakan sistem pendidikan tertua saat ini dan dianggap sebagai produk budaya Indonesia, Pesantren dengan sistem dan karakter tersendiri telah menjadi bagian integral dari suatu institusi sosial masyarakat, Fenomena globalisasi tidak mempengaruhi terhadapa keunikan pesantren yang masih tetap konsisten dengan menyuguhkan suatu sistem pendidikan yang mampu menjembatani kebutuhan fisik (jasmani) dan kebutuhan mental spiritual (rohani) manusia. Eksistensi pondok pesantren dalam menyikapi perkembangan zaman, Bahkan beberapa diantaranya muncul sebagai model gerakan alternatif bagi pemecah masalahmasalah sosial masyarakat. Sehingga keberadaan pesantren merupakan sebuah jawaban, bahwa pesantren merupakan tempat pendidikan dengan pola pendidikan yang mampu melahirkan sumber daya manusia (SDM) yang handal. Dan pesantren merupakan tempat pendidikan yang tidak lekang oleh zaman, dan tidak akan hilang dengan derasnya gelombang globalisasi, karena pesantren memiliki ciri khas tersendiri yang mampu bertahan dan mampu berubah kearah yang lebih baik di tengah-tengah zaman yang serba modern.
\end{abstract}

Kata Kunci: Pesantren, Global.

\section{A. PENDAhULUAN}

Di antara lembaga pendidikan yang pernah muncul di Indonesia, pendidikan keagamaan dalam bentuk pesantren merupakan sistem pendidikan tertua saat ini dan dianggap sebagai produk budaya Indonesia yang indigenoous (makna keaslian Indonesia). Pendidikan ini semula merupakan pendidikan agama Islam yang dimulai sejak munculnya masyarakat Islam di Nusantara pada abad ke-13. Beberapa abad kemudian penyelenggaraan pendidikan ini semakin teratur dengan munculnya tempat-tempat pengajian. Bentuk ini kemudian berkembang dengan pendirian tempat-tempat menginap bagi para pelajar (santri), yang kemudian disebut pesantren. ${ }^{2}$

Akar historis-kultural pesantren tidak terlepas dari masuk dan berkembanganya Islam di Indonesia pada abad ke-13 yang bercorak sufistik atau mistik. Dalam pergumulannya, pesantren banyak menyerap budaya masyarakat Jawa Kelurahan pada saat itu yang cenderung statis dan sinkretis.

Oleh karena itulah, disamping karena basis pesantren adalah masyarakat atau Islam tradisional. Santri tradisional berkeyakinan bahwa unsur batin (esensi) dari kehidupan keagamaan lebih penting dari pada bentuk lahir, namun kesalehan luar merupakan ekspresi iman batin sebagai media memperkokoh spiritualitas. ${ }^{3}$

Sejarah perkembangan pesantren telah memainkan peran dan sekaligus kontribusi penting dalam sejarah pembangunan Indonesia. Sebelum

\footnotetext{
${ }^{1}$ Dosen Tetap STAI Taruna Surabaya

${ }^{2}$ Depag RI, Pedoman Pembinaan Pondok Pesantren dan Madrasah Diniyah, (Jakarta: Ditjen Binbaga Islam, 2005), 1.

${ }^{3}$ M. Hasyim, Affan, Menggagas Pesantren Masa Depan, (Yogyakarta: CV. Qalam, 2003), 77. 273
} 
kolonial Belanda datang ke Indonesia, pesantren merupakan suatu lembaga yang berfungsi menyebarkan agama Islam dan mengadakan perubahanperubahan masyarakat kearah yang lebih baik-sebagaimana tercermin dalam pelbagai peranan pesantren terhadap kegiatan politik para raja dan pangeran di Jawa, kegiatan perdagangan, dan pembukaan daerah pemukiman baru.

Ketika Belanda menduduki kerajaan-kerajaan di Nusantara, pesantren menjadi pusat perlawanan dan pertahanan terhadap kolonial Belanda, juga Jepang dan Inggris. Bahkan setelah kemerdekaan pun, yakni 1959-1965-an, pesantren masih dikategorikan sebagai "alat revolusi" dan era orde baru. ${ }^{4}$

Kehadiran pondok pesantren telah nyata membantu pemerintah dalam rangka mencerdaskan kehidupan bangsa. Di samping itu, pesantren telah menawarkan jenis pendidikan alternatif bagi pengembangan pendidikan nasional. Sejak awal berdirinya pondok pesantren dikenal sebagai lembaga pengkaderan ulama, tempat pengajaran ilmu agama, dan memelihara tradisi Islam.

Fungsi ini semakin berkembang akibat tuntutan pembangunan nasional yang mengharuskan pesantren terlibat di dalamnya. Di tengah terpaaan arus globalisasi, para pakar ramai menyatakan bahwa dunia semakin kompleks dan saling ketergantungan. dikatakan pula bahwa perubahan yang akan terjadi dalam bentuk non-linear, tidak bersambung, dan tidak bisa diramalkan. Masa depan merupakan suatu ketidaksinambungan. Kita memerlukan pemikiran ulang dan rekayasa ulang terhadap masa depan yang akan dilewati. Kita berani tampil dengan pemikiran yang terbuka dan meninggalkan cara-cara lama yang tidak produktif. Fenomena globalisasi banyak melahirkan sifat individualisme dan pola hidup meterialistik yang kian mengental.

Di sinilah keunikan pondok pesantren yang masih tetap konsisten dengan menyuguhkan suatu sistem pendidikan yang mampu menjembatani kebutuhan fisik (jasmani) dan kebutuhan mental spiritual (rohani) manusia. Eksistensi pondok pesantren dalam menyikapi perkembangan zaman, tentunya memiliki komitmen untuk tetap menyuguhkan pola pendidikan yang mampu melahirkan sumber daya manusia (SDM) yang handal.

Menghadapi tantangan yang semakin kompleks di lingkungan masyarakat, maka pondok pesantren harus berani tampil dan mengembangkan dirinya sebagai pusat keunggulan jiwa, jalan hidup yang lurus, budi pekerti yang mulia, tetapi juga santri yang dibekali dengan berbagai disiplin ilmu keterampilan lainnya, guna dapat diwujudkan dan mengembangkan segenap kualitas yang dimilikinya.

Untuk mencapai tujuan di atas, para santri harus dibekali nilai-nilai ke-Islaman yang dipadukan dengan keterampilan dapat ditempuh dengan mempelajari tradisi ilmu pengetahuan keterampilan. Pembekalan ilmu dan keterampilan dapat ditempuh dengan mempelajari ilmu pengetahuan agama dan penggalian dari teknologi keterampilan umum. Mencermati karakteristik umat Islam serta kecenderungan perkembangan ilmu pengetahuan dan teknologi di masa yang akan datang, disertai dengan perkembangan kebudayaan, maka pilihan format pondok pesantren lebih menekankan pada

\footnotetext{
${ }^{4}$ Imam Tolkhah dan Ahmad Barizi, Membuka Jendela Pendidikan, (Jakarta: PT. Raja Grafindo Persada, 2004), 49.
} 
ilmu pengetahuan alam. Maka keberadaan pondok pesantren sangat optimis sebagai alternatif pendidikan. Di sinilah peran pesantren perlu ditingkatkan.

Tuntutan globalisasi tidak mungkin dihindari. Salah satu langkah yang bijak adalah mempersiapkan pesantren agar tidak "ketinggalan kereta" dan tidak kalah dalam persaingan. Pada tataran ini masih banyak pembenahan dan perbaikan yang harus dilakukan oleh pondok pesantren. Paling tidak ada tiga hal yang harus digarap oleh pondok pesantren yang sesuai dengan jati dirinya. Pertama, pesantren sebagai lembaga pendidikan pengkaderan ulama.

Fungsi ini tetap harus melekat pada pesantren, karena pesantren adalah satu-satunya lembaga pendidikan yang melahirkan ulama. Namun demikian, tuntutan modernisasi dan globalisasi mengharuskan ulama memiliki kemampuan lebih, kapasitas intelektual yang memadai, wawasan, akses pengetahuan dan informasi yang cukup serta responsif terhadap perkembangan dan perubahan zaman. Kedua, pesantren sebagai lembaga ilmu pengetahuan khusus agama Islam.

Pada tatanan ini, pesantren masih dianggap lemah dalam penguasaan ilmu dan metodologi. Pesantren hanya mengajarkan ilmu agama dalam arti transfer of knowledge. Karena pesantren harus jelas memiliki potensi sebagai "lahan" pengembangan ilmu agama. Ketiga, dunia pesantren harus mampu menempatkan dirinya sebagai transformator, motivator, dan inovator.

Kehadiran pesantren dewasa ini telah memainkan perannya sebagai fungsi tersebut, meskipun masih dalam taraf yang perlu dikembangkan lebih lanjut. Sebagai salah satu komponen masyarakat, pesantren memiliki kekuatan dan "daya tawar" untuk melakukan perubahan-perubahan yang berarti.

\section{B. PESANTREN MENURUT SEJARAH}

Secara Umum Pondok pesantren, menurut sejarah akar berdirinya di Indonesia, ditemukan dua versi pendapat. Pertama, pendapat yang menyebutkan bahwa pondok pesantren berakar pada tradisi Islam sendiri, yaitu tradisi tarekat. Pondok pesantren mempunyai kaitan yang erat dengan tempat pendidikan yang bagi kaum sufi.

Pendapat ini berdasarkan fakta bahwa penyiaran Islam di Indonesia pada awalnya lebih banyak dikenal dalam bentuk kegiatan tarekat. Hal ini ditandai dengan terbentuknya kelompok organisasi tarekat yang melaksanakan amalan-amalan zikir dan wirid tertentu. Kedua, pondok pesantren yang kita kenal sekarang ini pada mulanya merupakan pengambilalihan dari sistem pondok pesantren yang diadakan orang-orang Hindu di Nusantara. Hal ini didasarkan pada fakta bahwa jauh sebelum datangnya Islam ke Indonesia lembaga pondok pesantren sudah ada di negeri ini.

Pendirian pondok pesantren pada masa itu dimaksudkan sebagai tempat mengajarkan ajaran-ajaran agama Hindu. Fakta lain menunjukan bahwa pondok pesantren bukan berasal dari tradisi Islam adalah tidak ditemukannya lembaga pondok pesantren di negara-negara Islam lainnya.Pondok pesantren di Indonesia baru diketahui keberadaan dan perkembangannya setelah abad ke16. Karya-karya jawa klasik seperti serat cabolek dan serat centini mengungkapkan bahwa sejak permulaan abad ke-16 ini di Indonesia telah banyak dijumpai lembaga-lembaga yang mengajarkan berbagai kitab Islam 
klasik pada bidang fiqih, aqidah, tasawuf dan menjadi pusat-pusat penyiaran Islam yaitu pondok pesantren. ${ }^{5}$

Pesantren sendiri menurut pengertian dasarnya adalah "tempat belajar para santri". Sedangkan pondok berarti rumah atau tempat tinggal sederhana yang terbuat dari bambu. Disamping itu kata "pondok" mungkin juga berasal dari bahasa Arab "Funduk" yang berarti "Hotel atau Asrama". 6

Menurut Zuhairini yang ditulis oleh Hasbullah, ${ }^{7}$ secara garis besar, pesantren dapat dibedakan menjadi dua macam, yaitu:

a. Pesantren Tradisional Yaitu pesantren yang masih mempertahankan sistem pengajaran tradisional, dengan materi pengajaran kitab-kitab klasik yang sering disebut kitab kuning. Diantara pesantren ini ada yang mengelola madrasah, bahkan juga sekolah-sekolah umum mulai tingkat dasar atau menengah, dan ada pula pesantren-pesantren besar yang sampai ke perguruan tinggi. Murid-murid dan mahasiswa diperbolehkan tinggal dipondok atau di luar, tetapi mereka diwajibkan mengikuti pengajaran kitab-kitab denga cara sorogan maupun bandungan, sesuai dengan tingkatan masing-masing. Guru-guru pada madrasah atau sekolah pada umumnya mengikuti pengajian kitab-kitab pada perguruan tinggi negeri.

b. Pesantren Modern Merupakan pesantren yang berusaha mengintegrasikan secara penuh sistem klasikal dan sekolah ke dalam pondok pesantren. Semua santri yang masuk pondok terbagi dalam tingkatan kelas. Pengajian kitab-kitab klasik tidak lagi menonjol, bahkan ada yang hanya sekedar pelengkap, tetapi berubah menjadi mata pelajaran atau bidang studi. Begitu juga dengan sistem yang diterapkan, seperti cara sorogan dan bandungan mulai berubah menjadi individual dalam hal belajar dan kuliah secara umum, atau stadium general. Menurut M. Arifin yang ditulis oleh Hasbullah (1996:44), pondok pesantren merupakan lembaga pendidikan tradisional Islam untuk memahami, menghayati, dan mengamalkan ajaran agama Islam dengan menekankan pentingnya moral agama Islam sebagai pedoman hidup bermasyarakat sehari-hari.

Menurut Zamakhsyari Dhofier, ${ }^{8}$ terdapat lima elemen dasar dari tradisi pesantren yang sekaligus menunjukan unsur-unsur pokoknya, serta membedakannya dengan lembaga-lembaga pendidikan lainnya adalah sebagai berikut:

1. Pondok,

Sebuah pondok pesantren pada dasarnya adalah sebuah asrama pendidikan Islam tradisional di mana para siswanya tinggal bersama dan belajar di bawah bimbingan seorang (atau lebih) guru yang lebih dikenal dengan sebutan "kyai". Asrama untuk para siswa tersebut berada dalam lingkungan komplek pesantren di mana kyai bertempat tinggal yang juga menyediakan sebuah masjid untuk beribadah, ruang untuk belajar dan kegiatan-kegiatan keagamaan yang lain. Komplek pesantren ini biasanya

\footnotetext{
${ }^{5}$ Depag RI, Pola Pengembangan Pondok Pesantren,( Jakarta: Ditjen Binbaga Islam, 2003), 11.

${ }^{6}$ Dhofier, Zamakhsyari, Tradisi Pesantren, Studi tentang Pandangan Hidup Kyai, (Jakarta: LP3ES, 1982), 18.

${ }^{7}$ Hasbullah, Kapita Selekta Pendidikan Islam, (Jakarta: PT. Raja Grafindo Persada, 1996), 157.

${ }^{8}$ Dhofier, Zamakhsyari.............., 44. 
dikelilingi dengan tembok untuk dapat mengawasi keluar dan masuknya para santri sesuai dengan peraturan yang berlaku.

Ada tiga alasan utama pesantren harus menyediakan asrama bagi para santri. Pertama, kemasyhuran seorang kyai dan kedalaman pengetahuannya tentang Islam menarik santri-santri dari jauh. Untuk dapat menggali ilmu dari kyai tersebut secara teratur dan dalam waktu yang lama, para santri tersebut harus meninggalkan kampung halamannya dan menetap di dekat kediaman kyai. Kedua, hampir semua pesantren berada di desa-desa di mana tidak tersedia perumahan yang cukup untuk dapat menampung santri-santri, dengan demikian perlu adanya suatu asrama khusus bagi para santri. Ketiga, ada sikap timbal balik antara kyai dan santri, di mana para santri menganggap kyainya seolah-olah sebagai bapaknya sendiri, sedangkan kyai menganggap para santri sebagai titipan Tuhan yang harus senantiasa dilindungi. Sikap timbal balik ini menimbulkan keakraban dan kebutuhan untuk saling berdekatan terus-menerus. Sikap ini juga menimbulkan perasaan tanggung jawab di pihak kyai untuk dapat menyediakan tempat tinggal bagi para santri.

Di samping itu dari pihak santri tumbuh perasaan pengabdian kepada kyainya, sehingga para kyai memperoleh imbalan dari para santri sebagai sumber tenaga bagi kepetingan pesantren dan keluarga kyai.

Pentingnya pondok pesantren sebagai asrama para santri tergantung kepada jumlah santri yang datang dari daerah-daerah yang jauh. Untuk pesantren kecil, para santri banyak yang tinggal di rumah-rumah penduduk di sekitar pesantren, mereka menggunakan pondok hanya untuk keperluankeperluan tertentu saja.

Pondok tempat tinggal santri wanita biasanya dipisahkan dengan pondok untuk laki-laki, selain dipisahkan oleh rumah kyai dan keluarganya, juga oleh masjid dan ruang-ruang madrasah. Sistem pondok bukan saja merupakan elemen penting dari tradisi pesantren, tetapi juga menopang utama bagi pesantren untuk dapat terus berkembang.

2. Masjid,

Masjid merupakan elemen yang tidak dapat dipisahkan dengan pesantren dan dianggap sebagai tempat yang paling tepat untuk mendidik para santri, terutama dalam praktek sembahyang lima waktu, khutbah dan sembahyang jum'ah, dan pengajaran kitab-kitab Islam klasik.

Para kyai selalu mengajar murid-muridnya di masjid dan menganggap masjid sebagai tempat yang paling tepat untuk menanamkan disiplin para murid dalam mengerjakan kewajiban sembahyang lima waktu, memperoleh pengetahuan agama dan kewajiban agama yang lain.

Seorang kyai yang ingin mengembangkan sebuah pesantren, biasanya pertama-tama akan mendirikan masjid di dekat rumahnya. Langkah ini biasanya diambil atas perintah gurunya yang telah menilai bahwa ia akan sanggup memimpin sebuah pesantren. Masjid adalah sebagai pusat kegiatan ibadah dan belajar mengajar.

Masjid merupakan sentral sebuah pesantren karena disinilah pada tahap awal bertumpu seluruh kegiatan di lingkungan pesantren, baik yang 
berkaitan dengan ibadah, shalat berjamaah, zikir, wirid, do'a, i'tiqaf, dan juga kegiatan belajar-mengajar. ${ }^{9}$

\section{Kitab-kitab Klasik}

Unsur pokok lain yang cukup membedakan pesantren dengan lembaga pendidikan lainnya adalah bahwa pada pesantren diajarkan kitabkitab Islam klasik atau yang sekarang terkenal dengan sebutan kitab kuning, yang dikarang oleh para ulama terdahulu mengenai berbagai macam ilmu pengetahuan agama Islam dan bahasa arab. Pelajaran dimulai dengan kitab-kitab yang sederhana, kemudian dilanjutkan dengan kitabkitab tentang berbagai ilmu yang mendalam. Tingkatan suatu pesantren dan pengajarannya, biasa diketahui dari jenis kitab-kitab yang diajarkan. ${ }^{10}$

Tujuan utama pengajaran ini ialah untuk mendidik calon-calon ulama. Para santri yang bercita-cita ingin menjadi ulama, mengembangkan keahliannya dalam bahasa Arab melalui sistem sorogan dalam pengajian sebelum mereka pergi ke pesantren untuk mengikuti sistem bandongan.

Meskipun kebanyakan pesantren telah memasukan pengajaran pengetahuan umum sebagai suatu bagian penting dalam pendidikan pesantren, namun pengajaran kitab-kitab Isalm klasik tetap diberikan sebagai upaya untuk meneruskan tujuan utama pesantren mendidik caloncalon ulama, yang setia kepada faham Islam tradisional.

Keseluruhan kitab-kitab klasik yang diajarkan di pesantren dapat digolongkan kedalam 8 kelompok:

1. nahwu (syntax) dan saraf (morfologi);

2. fiqh;

3. usul fiqh;

4. hadis;

5. tafsir;

6. tauhid;

7. tasawuf dan etika, dan

8. cabang-cabang lain seperti tarikh dan balaghah.

Kitab-kitab tersebut meliputi teks yang sangat sampai pendek sampai teks yang terdiri dari berjilid-jilid tebal mengenai hadis, tafsir, fiqh, usul fiqh, dan tasawuf. Kesemuanya ini dapat pula digolongkan kedalam tiga kelompok yaitu:

1. kitab-kitab dasar;

2. kitab-kitab tingkat menengah;

3.. kitab-kitab besar.

Seorang kyai yang memimpin pesantren kecil mengajar sejumlah kecil santri tentang beberapa kitab dasar dalam berbagai kelompok pelajaran. Dalam pesantren besar, masing-masing kyai mengkhususkan diri dalam mata pelajaran-pelajaran tertentu. Sistem pendidikan pesantren yang tradisional ini, yang biasanya dianggap sangat "statis" dalam mengikuti sistem sorogan dan bandongan dalam menerjemahkan kitab-kitab klasik ke

\footnotetext{
${ }^{9}$ Yasmadi, Modernisasi Pesantren, Krituk Nurcholish Madjid terhadap Pendidikan Islam Tradisional, (Edisi Revisi, Ciputat: Quantum Teaching, 2002), 64.

${ }^{10}$ Hasbullah, Sejarah Pendidikan Islam di Indonesia, (PT. Raja Grafindo Persada, 1995), 50.
} 
dalam bahasa Jawa, dalam kenyataannya tidak hanya sekedar membicarakan bentuk dengan melupakan isi ajaran yang tertuang dalam kitab-kitab tersebut.

Para kyai sebagai pembaca dan penerjamah kitab tersebut, bukanlah sekedar "membaca teks, tetapi juga memberikan pandanganpandangan pribadi, baik mengenai isi maupun bahasa dari teks.

Dengan kata lain, para kyai tersebut memberikan pula komentar atas teks sebagai pandangan pribadinya. Oleh karena itu, para penerjermah tersebut haruslah menguasai tatabahasa Arab, literatur dan cabang-cabang pengetahuan agama Islam yang lain.

Menurut Faisal Ismail sebagaimana dikutip oleh Yasmadi, ${ }^{11}$ penggalian khasanah budaya Islam melalui kitab-kitab klasik salah satu unsur yang terpenting dari keberadaan sebuah pesantren dan yang membedakannya dengan lembaga pendidikan yang lainnya. Pesantren sebagai lembaga pendidikan Islam tradisional tidak dapat diragukan lagi berperan sebagai pusat transmisi dan desiminasi ilmu-ilmu keislaman, terutama yang bersifat kajian-kajian klasik. Maka pengajaran "kitab-kitab kuning" telah menjadi karakteristik yang merupakan ciri khas dari proses belajar mengajar di pesantren.

4. Santri

Santri menurut tradisi pesantren terdapat 2 kelompok santri:

1. Santri mukmin yaitu murid-murid yang berasal dari daerah yang jauh dan menetap dalam kelompok pesantren. Santri mukmin yang paling lama tinggal di pesantren tersebut biasanya merupakan satu kelompok tersendiri yang memegang tanggungjawab mengurusi kepentingan pesantren sehari-hari; mereka juga memikul tanggungjawab mengajar santri-santri muda tentang kitab-kitab dasar menengah.

2. Santri kalong yaitu murid-murid yang berasal dari desa-desa di sekeliling pesantren, yang biasanya tidak menetap dalam pesantren. Untuk mengikuti pelajarannya di pesantren, mereka bolak-balik dari rumahnya sendiri. Yang membedakan antara pesantren besar dengan pesantren kecil biasanya terletak pada komposisi atau perbandingan antara kedua kelompok santri tersebut.

Biasanya pesantren-pesantren besar memiliki santri mukmin yang lebih besar dari santri kalong, sedang pesantren yang tergolong kecil, mempunyai lebih banyak santri kalong. Seorang santri pergi dan menetap di suatu pesantren karena berbagai alasan:

1) Ia ingin mempelajari kitab-kitab lain yang membahas Islam secara lebih mendalam di bawah bimbingan kyai yang memimpin pesantren tersebut.

2) Ia ingin memperoleh pengalaman kehidupan pesantren, baik dalam bidang pengajaran, keorganisasian maupun hubungan dengan pesantrenpesantren yang terkenal.

3) Ia ingin memusatkan studinya di pesantren tanpa disibukan oleh kewajiban sehari-hari di rumah keluarganya.

${ }^{11}$ Yasmadi, Modernisasi Pesantren, 67. 
Di samping itu, rumahnya sendiri ia tidak mudah pulang-balik meskipun kada ng-kadang menginginkannya.

5. Kyai

Kyai merupakan elemen yang paling esensial dari suatu pesantren. Ia sering kali bahkan merupakan pendirinya. Sudah sewajarnya bahwa pertumbuhan suatu pesantren semata-mata bergantung kepada kemampuan pribadi kyainya. Menurut asal-usulnya, perkataan kyai dalam bahasa jawa dipakai untuk tiga jenis gelar yang saling berbeda:

1) Sebagai gelar kehormatan bagi barang-barang yang dianggap keramat; umpamanya, "Kyai Garuda Kencana" dipakai untuk sebutan Kereta Emas yang ada di Keraton Yogyakarta.

2) Gelar kehormatan untuk orang-orang tua pada umumnya

3) Gelar yang diberikan oleh masyarakat kepada seorang ahli agama Islam yang memiliki atau menjadi pimpinan pesantren dan mengajar kitab-kitab Islam klasik kepada para santrinya. Selain gelar kyai, ia juga sering disebut seorang alim (orang yang memiliki pengetahuan tentang Islam secara mendalam).

Para kyai dengan kelebihan pengetahuannya dalam Islam, seringkali dilihat sebagai orang yang senantiasa dapat memahami keagungan Tuhan dan rahasia alam, hingga dengan demikian mereka dianggap memiliki kedudukan yang tak terjangkau, terutama oleh kebanyakan orang awam.

Dalam beberapa hal, mereka menunjukan kekhususan mereka dalam bentuk-bentuk pakaian yang merupakan simbol kealiman yaitu kopiah dan sorban. Untuk menjadi seorang kyai, pertama-tama ia biasanya merupakan anggota keluarga kyai. Setelah menyelesaikan pelajarannya di berbagai pesantren, kyai pembimbingnya yang terakhir akan melatihnya untuk mendirikan pesantren sendiri.

Kadang-kadang kyai pembimbing tersebut turut secara langsung dalam pendirian proyek pesantren yang baru, sebab kyai yang muda ini dianggap mempunyai potensi untuk menjadi seorang alim yang baik. Campurtangan kyai biasanya lebih banyak lagi; antara lain calon kyai tersebut dicarikan jodoh, dan diberi didikan istimewa agar menggunakan waktu terakhirnya di pesantren khusus untuk mengembangkan bakat kepemimpinannya.

Masyarakat biasanya mengharapkan seorang kyai dapat menyelesaikan persoalan-persoalan keagamaan praktis sesuai dengan kedalaman pengetahuan yang dimilikinya. Semakin tinggi kitab-kitab yang diajarkan, ia akan semakin dikagumi. Ia juga diharapkan dapat menunjukkan kepemimpinannya, kepercayaannya kepada diri sendiri dan kemampuannya, karena banyak orang datang meminta nasehat dan bimbingan dalam banyak hal. Ia juga diharapkan untuk rendah hati, menghormati semua orang, tanpa melihat tinggi rendah kelas sosialnya, kekayaan dan pendidikannya, banyak prihatin dan penuh pengabdian kepada Tuhan dan tidak pernah berhenti memberikan kepemimpinan keagamaan, seperti memimpin sembahyang lima waktu, memberikan khutbah jum'ah dan menerima undangan perkawinan, kematian dan lain-lain.

Adanya kyai dalam pesantren merupakan hal yang mutlak bagi sebuah pesantren, sebab dia adalah tokoh sentral yang memberikan pengajaran, 
karena kyai menjadi salah satu unsur yang paling dominan dalam kehidupan suatu pesantren. Hubungan antara guru dan murid adalah sedemikian rupa sehingga anjuran-anjuran yang diberikan oleh sang guru dianggap oleh murid sebagai perintah yang mutlak harus dikerjakan. ${ }^{12}$

Kemasyhuran, perkembangan dan kelangsungan suatu pesantren banyak bergantung pada keahlian dan ke dalam ilmu, kharismatik, wibawa dan ketrampilan kyai yang bersangkutan dalam mengelola pesantrennya. ${ }^{13}$ Oleh sebab ketokohan kyai di atas, banyak pesantren akhirnya bubar lantaran ditinggal wafat kyainya. Sementara kyai tidak memiliki keturunan yang dapat melanjutkan usahanya.

Menurut Faisal Ismail yang ditulis oleh Yasmadi, ${ }^{14}$ kyai dapat juga dikatakan tokoh non formal yang ucapan-ucapan dan seluruh perilakunya akan dicontoh oleh komunitas di sekitarnya. Kyai berfungsi sebagai sosok model atau teladan yang baik (uswah hasanah) tidak saja bagi santrinya, tetapi juga bagi seluruh komunitas di sekitar pesantren. Secara umum pondok pesantren memiliki fungsi-fungsi sebagai: ${ }^{15}$

(1) lembaga pendidikan yang melakukan transfer ilmu-ilmu agama (tafaqquh fi aldin) dan nilai-nilai Islam (Islamic values),

(2) lembaga keagamaan yang melakukan kontrol sosial (social control), dan

(3) lembaga keagamaan yang melakukan rekayasa sosial (social engineerimg)

Menurut Imam Tolkhah dan Ahmad Barizi, ${ }^{16}$ pada dasarnya pesantren dibangun atas keinginan bersama dua komunitas yang saling bertemu. Yaitu komunitas santri yang ingin menimba ilmu sebagai bekal hidup dan kyai/guru yang secara ikhlas ingin mengajarkan ilmu dan pengalamannya.

Kyai dan santri adalah dua entitas yang memiliki kesadaran yang sama untuk secara bersama-sama membangun komunitas keagamaan yang disebut pesantren. Kyai, ustadz, dan santri hidup di satu kampus berlandaskan nilai-nilai agama Islam yang dilengkapi dengan norma-norma dam kebiasaan-kebiasaan sendiri Komunitas keagamaan pesantren dilandasi oleh keinginan bertafaqquh fi al-din (mendalami atau mengkaji agama) dengan kaidah al-muhafzhah ala alqadim al shalih wa al-akhdaz bi al-ashlah (memelihara tradisi lama yang abim dan mengambil tradisi baru yang lebih baik).

\section{MENGENAL PENDIDIKAN DI PESANTREN}

Pesantren atau pondok adalah lembaga yang merupakan wujud proses wajar perkembangan sistem pendidikan nasional. Dari segi historis pesantren tidak hanya identik dengan makna keislaman, tetapi juga mengandung makna keaslian Indonesia (indigenous). Sebab, lembaga yang serupa pesantren ini

\footnotetext{
${ }^{12}$ Dhofier, Zamakhsyari, Tradisi Pesantren, Studi tentang Pandangan Hidup Kyai, (Jakarta: LP3ES, 1982), 23.

${ }^{13}$ Hasbullah, Sejarah Pendidikan Islam di Indonesia, (PT. Raja Grafindo Persada, 1995), 49.

${ }^{14}$ Yasmadi, Modernisasi Pesantren, ............, 64.

${ }^{15}$ Depag RI, Pedoman Pembinaan Pondok Pesantren dan Madrasah Diniyah, (Jakarta: Ditjen Binbga Islam, 2005), 7.

${ }^{16}$ Imam Tolkhah dan Ahmad Barizi, Membuka Jendela Pendidikan, (Jakarta: PT. Raja Grafindo Persada, 2004), 55.
} 
sebanarnya sudah ada sejak pada masa kekuasaan Hindu-Budda. Sehingga Islam tinggal meneruskan dan mengislamkan lembaga pendidikan yang sudah ada. ${ }^{17}$

Dalam pelaksanaan pendidikan yang diselenggarakan pondok pesantren, secara garis besar dapat digolongkan ke dalam dua bentuk yang penting:

a. Pondok Pesantren Salafiyah

Pondok Pesantren Salafiyah adalah pondok pesantren yang menyelenggarakan pengajaran Al-Quran dan ilmu-ilmu agama Islam yang kegiatan pendidikan dan pengajarannya sebagaimana yang berlangsung sejak awal pertumbuhannya. Pembelajaran (pendidikan dan pengajaran) yang ada pada pondok pesantren ini dapat diselenggarakan dengan cara non-klasikal atau dengan klasikal. Jenis pondok ini pun dapat meningkat dengan membuat kurikulum sendiri, dalam arti kurikulum ala pondok pesantren yang bersangkutan yang disusun sendiri berdasarkan ciri khas yang dimiliki oleh pondok pesantren. Penjenjangan dilakukan dengan cara memberikan kitab pegangan yang lebih tinggi dengan funun (tema kitab) yang sama, setelah tamatnya suatu kitab. Para santri dapat tinggal dalam asrama yang disediakan dalam lingkungan pondok pesantren, dapat juga mereka tinggal di luar lingkungan pondok pesantren (santri kalong).

b. Pondok Pesantren Khalafiyah (Ashriyah)

Pondok Pesantren Khalafiyah adalah pondok pesantren yang selain menyelenggarakan kegiatan kepesantrenan, juga menyelenggarakan kegiatan pendidikan formal (jalur sekolah), baik itu jalur sekolah umum (SD, SMP, SMU, dan SMK), maupun jalur sekolah ciri khas agama Islam (MI, MTs, MA, atau MAK).

Pondok Pesantren Salafiah yang menambah lembaga pendidikan formal dalam pendidikan dan pengajarannya. Penjenjangan yang dilakukan berdasarkan pada sekolah formalnya atau berdasarkan pengajiannya. Para santri yang ada di pondok pesantren tersebut pun adakalanya"mondok", dalam arti sebagai santri dan sebagai siswa sekolah. Adakalanya pula sebagian siswa lembaga sekolah bukan santri pondok pesantren, hanya ikut pada lembaga formal saja. Bahkan dapat pula santrinya hanya mengikuti pendidikan kepesantrenan saja. ${ }^{18}$

Penamaan batasan penjenjangan pun bermacam-macam. Ada yang mempergunakan istilah marhalah, sanah, dan lainnya. Bahkan adapula yang bertingkat seperti Madrasah Formal, Ula, Wustho dan 'Ulya. Dalam kaitannya dengan pondok pesantren, ajaran adalah apa yang terdapat dalam kitab kuning atau kitab rujukan atau referensi yang dipegang oleh pondok pesantren tersebut. Santri tradisional berkeyakinan bahwa unsur batin (esensi) dari kehidupan keagamaan lebih penting, namun kesalehan luar merupakan ekpresi iman batin sebagai media memperkokoh spritualitas. ${ }^{19}$

Pemahaman terhadap teks-teks ajaran tersebut dapat dicapai melalui metode pembelajaran tertentu yang biasa digunakan oleh pondok pesantren.

\footnotetext{
${ }^{17}$ Madjid, Nurcholish, Bililk-Bilik Pesantren, Sebuah Potret Perjalanan,( Jakarta: Paramadina, 1997), 3

${ }^{18}$ Depag RI, Pola Pengembangan Pondok Pesantren, (Jakarta: Ditjen Binbaga Islam, 2003), 41

${ }^{19}$ M. Hasyim, Affan, Menggagas Pesantren Masa Depan,( Yogyakarta: CV. Qalam, 2003), 77.
} 
Selama kurun waktu yang panjang, pondok pesantren telah memperkenalkan dan menerapkan beberapa metode weton dan bandongan, sorogan dan hafalan (tahfidz).

Terdapat beberapa metode-metode dalam system pembelajaran di pesantren, metode tersebut dapat kita jumpai antara lain :

1. Metode Wetonan atau Bandongan

Metode weton atau bandongan ini adalah cara penyampaian ajaran kitab kuning di mana seorang guru, kyai, atau ustadz membaca dan menjelaskan isi ajaran/kitab kuning tersebut, sementara santri, murid atau siswa mendengarkan, memaknai dan menerima. Dalam metode ini, guru berperan aktif, sementara murid bersukap pasif.

Dalam sistem wetonan ini sekelompok murid (antara 5 sampai 500) mendengarkan seorang guru yang membaca, menerjemahkan, menerangkan dan seringkali mengulas buku-buku Islam dalam bahasa Arab. Setiap murid memperhatikan bukunya sendiri dan membuat catatan-catatan tentang katakata atau buah pikiran yang sulit. Kelompok kelas dari sistem ini disebut halaqah.

Dalam sistem ini juga, seorang murid tidak harus menunjukan bahwa ia mengerti pelajaran yang dihadapi. Para kyai biasanya membaca, menerjemahkan kalimat-kalimat secara cepat dan tidak menerjemahkan katakata yang mudah. Dengan cara ini, kyai dapat menyelesaikan kitab-kitab pendek dalam beberapa minggu saja. ${ }^{20}$ Weton adalah pengajian yang inisiatifnya berasal dari kyai sendiri, baik dalam menentukan tempat, waktu, maupun kitab-kitabnya. ${ }^{21}$

2. Metode Sorogan

Dalam metode sorogan, sebaliknya, santri yang menyodorkan kitab (sorog) yang akan dibahas dan sang guru mendengarkan, setelah itu beliau memberikan komentar dan bimbingan yang dianggap perlu bagi santri. Sistem sorogan ini memungkinkan seorang guru mengawasi, menilai dan membimbing secara maksimal kemampuan seorang murid dalam menguasai bahasa Arab. ${ }^{22}$ Sorogan adalah pengajian yang merupakan permintaan dari seorang atau beberapa santri kepada kyainya untuk diajari kitab tertentu. Pengajian sorogan biasanya hanya diberikan kepada santri-santri yang cukup maju, khusunya yang berminat hendak menjadi kyai. ${ }^{23}$

3. Metode Hafalan (Tahfidz)

Metode ini telah menjadi ciri yang melekat pada sistem pendidikan tradisional, termasuk pondok pesantren. Hal ini sangat penting pada sistem keilmuan yang lebih mengutamakan argumen naqli, transmisi dan periwayatan (normatif). Akan tetapi ketika konsep keilmuan lebih menekankan rasionalitas seperti yang menjadi dasar sistem pendidikan modern, metode hafalan kurang dianggap penting. Sebaliknya yang penting adalah kreativitas dan kemampuan mengembangkan pengetahuan yang dimiliki. Memang keberadaan metode hafalan ini masih perlu dipertahankan,

\footnotetext{
${ }^{20}$ Dhofier, Zamakhsyari, Tradisi Pesantren, Studi tentang Pandangan Hidup Kyai, (Jakarta: LP3ES, 1982,) 30.

${ }^{21}$ Madjid, Nurcholish, Bililk-Bilik Pesantren, Sebuah Potret Perjalanan, (Jakarta: Paramadina, 1997), 28.

${ }^{22}$ Dhofier, Zamakhsyari........., 29.

${ }^{23}$ Madjid, Nurcholish,..........., 28.

283
} 
sepanjang berkaitan dengan penggunaan argumen naqli dan kaidah-kaidah umum. Metode inipun masih relevan untuk diberikan kepada murid-murid usia anak-anak, tingkat dasar dan menengah. Pada usia tingkat atas sebaiknya dikurangi dengan mempergunakan metode ini pada rumus-rumus dan kaidahkaidah. Penekanan utama diberikan pada metode pemahaman dan diskusi.

4. Metode Diskusi (musyawarah/munazharah/mudzakarah)

Metode ini berarti penyajian bahan pelajaran dilakukan dengan cara murid atau santri membahasnya bersama-sama melalui tukar pendapat tentang suatu topik atau masalah tertentu yang ada dalam kitab kuning. Dalam kegiatan ini kyai atau guru bertindak sebagai "moderator". Dengan metode ini diharapkan dapat memacu para santri untuk dapat lebih aktif dalam belajar. Melalui metode ini akan tumbuh dan berkembang pemikiranpemikiran kritis, analitis dan logis. Adapun kegiatan mudzakarah dapat diartikan sebagai pertemuan ilmiah yang membahas masalah diniyah. Kegiatan ini dibedakan menjadi dua macam berdasarkan peserta yang disertakan, mudzakarah yang diadakan sesama kyai dan para ulama dan mudzakarah yang diselenggarakan sesama santri atau siswa, yang keduanya membahas masalah keagamaan.

5. Sistem Majelis Taklim (musyawarah/munazharah)

Metode yang digunakan adalah pembelajaran dengan cara ceramah, biasanya disampaikan dalam kegiatan tabligh atau kuliah umum. Proses pembelajaran kitab dapat pula dilakukan melalui penulisan karya ilmiah, sekurang-kurangnya dengan menulis resume atau ikhtisar atas topik yang ada dalam kitab kuning. ${ }^{24}$

Dan masih banyak metode-metode yang bisa kita jumpai di beberapa pondok pesantren, yang tentunya setiap pondok pesantren memiliki cirri dan karakter sendiri-sendiri, dan yang sering menjadi dorotan adalah terkait dengan kitab yang menjadi kajian di dalam pondok pesantren tersebut, terutama adalah kitab kuning, Menurut Azyumardi Azra yang dikutip oleh Imam Tholkhah dan Ahmad Barizi, ${ }^{25}$ kitab kuning adalah kitab-kitab keagamaan berbahasa Arab, Melayu, Jawa, atau bahasa-bahasa lokal lain di Indonesia dengan menggunakan aksara Arab, yang ditulis oleh ulama di Timur Tengah, juga ditulis oleh ulama itu sendiri.

Di dunia pesantren, kitab kuning juga kerap kali disebut dengan "kitab klasik" (al-kutub al-qadimah) atau "kitab kuno" karena memang ini merupakan produksi masa lampau, yaitu sebelum abad ke-17-an M, atau khususnya masa lahirnya empat mazhab terbesar dalam Islam, yaitu Imam Hanafi, Imam Malik, Imam Syafi'i, dan Imam Hambali. Kitab kuning juga disebut dengan "kitab gundul" karena bentuk-bentuk hurufnya kadang tanpa disertakan sandangan.

Sebagai sebuah aktifitas intelektual, kitab kuning sebenarnya sudah muncul di Indonesia sejak abad ke-16. Pada saat itu, kitab kuning merupakan referensi informal untuk mempelajari Islam dengan menggunakan tiga bahasa yaitu: bahasa Arab, Melayu, dan Jawa. Abad ke-18 kitab kuning menjadi referensi utama di lembaga-lembaga pendidikan Islam formal, seperti pesantren

\footnotetext{
${ }^{24}$ Depag RI, Pola Pengembangan Pondok Pesantren, (Jakarta: Ditjen Binbaga Islam, 2003), 47.

${ }^{25}$ Imam Tolkhah dan Ahmad Barizi, Membuka Jendela Pendidikan, (Jakarta: PT. Raja Grafindo Persada, 2004), 74.
} 
dan madrasah. Kemudian sejak abad ke-19 secara massal dan permanen kitab kuning diajarkan di pesantren dan madrasah, khususnya setelah banyak ulama Indonesia yang habis pulang dari Tanah Suci Makkah.

Kitab kuning memiliki peran strategis di dalam transformasi keilmuan di pesantren, bahkan ia merupakan referensi tunggal paling dini dalam tradisi intelektual Islam Nusantara karena dokumentasi keilmuan Islam yang kebanyakan berbahasa Arab. Kitab kuning dijadikan referensi utama di pesantren dan bahkan satu-satunya, karena keadaan bacaan dan keilmuan Islam pada masa-masa awal cukup representatif bagi problematika santri dan masyarakat. Kitab kuning dalam tradisi intelektual Islam awal di Nusantara cukup memenuhi kriteria kebenaran dalam menjawab problematika keagamaan yang dihadapi masyarakat. Kerangka pendekatan metodelogis pembelajaran kitab kuning melalui ilmu-ilmu sosial -seperti sosiologi, antropologi, maupun psikologi-merupakan keniscayaan untuk memahami substansi ajaran yang dikandungnya.

Paradigma pendekatan sosio-historis juga dikatakan sebagai keniscayaan karena bagaimanapun konstruksi kitab kuning tidak bisa dilepaskan dari kaitan waktu dan tempat. Aspek lokalitas memberiakn kontribusi yang cukup berperanan bagi konstruksi kitab kuning-dengan tanpa menafikan prinsip umum dari ajaran agama yang ada. Hal lain yang mendasari pentingnya paradigma sosio-historis dalam kajian kitab kuning adalah hakekat dan watak agama Islam sendiri.

Watak agama Islam yang secara absolut harus diikuti tentunya juga bergantung pada signifikansi dan relasionalitas penafsiran yang dibangun adalah Al- Quran dan hadist-hadist mutawatir. Watak dasar selanjutnya, Al-Quran secara umum tidak membawa ajaran-ajaran dalam bentuk tata cara pelaksanaan ajaran itu secara rinci. Al-Quran hadir dalam bentuk prinsip-prinsip dan ajaranajaran dasarnya saja. Tidak semua ayat-ayat Al-Quran bersifat jelas qath'ty aldalalah (arti dan maksudnya secara tekstual dan absolut kebenarannya), akan tetapi sebagian bersifat zhanny al-dalalah (samar-samar, tidak pasti atau tidak absolut arti dan maksudnya secara tekstual ). ${ }^{26}$

Waktu pembelajaran di pondok pesantren biasannya adalah setelah shalat subuh berjamaah di masjid, setelah shalat ashar dan setelah shalat isya. Pengajian ini dilakukan secara berjenjang atau secara keseluruhan , tergantung metode atau sistem penyelenggaraan yang dilakukan. Sedangkan waktu pagi sampai siang, biasanya diisi dengan kegiatan mandiri atau ketrampilan khusus yang diselenggarakan oleh pondok pesantren.

Jika ada pendidikan formal maka waktu pagi sampai siang ini yang diamnfaatkan untuk sekolah atau jika pondok pesantren tidak menyelenggarakan pendidikan formal atau ketrampilan, biasanya para santri ikut pendidikan formal di luar pondok pesantren atau mereka bekerja atau membantu kegiatan yang ada di lingkungan pondok pesantren. ${ }^{27}$

Dan perlu kita ketahui pula bahwa, dalam tradisi pesantren dikenal pula sistem pemberian ijazah, tetapi bentuknya tidak seperti yang kita kenal dalam sistem modern. Ijazah model pesantren itu berbentuk pencantuman nama dalam

\footnotetext{
${ }^{26}$ Imam Tolkhah dan Ahmad Barizi, Membuka Jendela Pendidikan, (Jakarta: PT. Raja Grafindo Persada, 2004), 74.

${ }^{27}$ Depag RI, Pola Pengembangan Pondok Pesantren, (Jakarta: Ditjen Binbaga Islam, 2003), 49. 285
} 
suatu daftar rantai transmisi pengetahuan yang dikeluarkan oleh gurunya terhadap muridnya yang telah menyelesaikan pelajarannya dengan baik tentang suatu buku tertentu sehingga murid tersebut dianggap menguasai dan mengajarkannya kepada orang lain.

Tradisi ijazah ini hanya dikeluarkan untuk murid-murid tingkat tinggi dan hanya mengenai kitab-kitab besar dan masyhur. Para murid yang telah memcapai suatu tingkatan pengetahuan tertentu tetapi tidak dapat mencapai ke tingkat yang cukup tinggi disarankan untuk membuka pengajian, sedangkan yang memiliki ijazah biasanya dibantu untuk mendirikan pesantren.

\section{INTERAKSI MASYARAKAT DENGAN PESANTREN}

Realitas menunjukan, pada satu sisi, sebagian besar penduduk Indonesia terdiri dari umat Islam, dan pada sisi lain, mayoritas dari mereka tinggal di Kelurahan. ${ }^{28}$ Pondok pesantren selain sebagai lembaga pendidikan keagamaan (tafaqquh fiddin) juga berfungsi sebagai lembaga pengembangan sosial masyarakat, karena tumbuh dan berkembangannya ada ditengah-tengah masyarakat.

Pengembangan potensi sosial diarahkan pada keamampuan pesantren dalam menganalisis sosial (Ansos), advokasi kepada yang lemah pada problemproblem yang terjadi di masyarakat, seperti keterbelakangan, kebodohan, kemiskinan, serta dekadensi social. ${ }^{29}$

Pondok Pesantren juga mempunyai peranan dalam transformasi masyarakat, diantaranya: ${ }^{30}$

1. Peranan instrumental dan fasilisator

2. Peranan mobilisasi

3. Peranan sumber daya manusia

4. Perubahan sosial

5. Pusat keagamaan, pendidikan, dan pengembangan masyarakat.

Pondok pesantren juga merupakan institusi yang telah memberikan sumbangan besar bagi pemeliharaan tata nilai dan peri kehidupan beragama yang sangat dibutuhkan dalam bangunan sosial agama. Posisi demikian disebabkan oleh kemampuan pesantren menciptakan suatu sikap hidup universal yang merata, kemampuan memelihara sub-kulturnya sendiri serta cara pandang santri dalam menilai lingkungan sosialnya yang memperlihatkan fleksibilitas ditengah ketatnya kaidah fiqih yang diyakininya.

Begitu juga dengan kedekatan dan keeratan para kyai terhadap masyarakat dengan segala problematika umat yang kompleks. Sehingga dalam kehidupan sehari-hari pesantren dengan figur kyainya menyediakan diri sebagai pemecah permasalaahn (problem solving), tempat masyarakat mengadukan hampir seluruh persoalan kehidupan baik sosial, hukum, budaya, ekonomi, politik, kesehatan, kesemuanya diselesaikan dengan sumbangsih kyai.

Corak dan ragam masyarakat yang heterogen itulah akhirnya memberikan dampak dominan dan mendorong keragaman kyai dan pesantren itu sendiri, yang satu sama lainnya bisa saling mengisi dan menyempurnakan. Hal

\footnotetext{
${ }^{28}$ A'la, Abd, Pembaruan Pesantren, (Yogyakarta: Pustaka Pesantren, 2006), 1.

${ }^{29}$ Depag RI, Pedoman Pembinaan Pondok Pesantren dan Madrasah Diniyah, (Jakarta: Ditjen Binbga Islam, 2005), 33.

${ }^{30}$ Depag RI, Pola Pengembangan Pondok Pesantren, (Jakarta: Ditjen Binbaga Islam, 2003), 93. 286
} 
inilah yang akan menciptakan kehidupan pesantren menjadi lebih dinamis dan berkualitas. ${ }^{31}$

Pesantren sesuai dengan peranan politik kemasyarakatannya berada dalam tatanan hubungan yang mempunyai tiga komponen yaitu: pesantren (dan/atau kyai), masyarakat, serta kelembagaan negara (pemerintah daerah/lingkungan instansi negara). Hubungan antara pesantren dan masyarakat sangat erat dan pimpinan Kelurahan seringkali mewakili kedua unsur tersebut, maka mereka mewakili kepentingan bersama sebagai kesatuan dalam menghadapi instansi-instansi diluar lingkungan Kelurahan.

Dalam masyarakat, pesantren dan para pemimpinannya memperoleh kedudukan yang tinggi. Dalam masyarakat Islam Kelurahan arti "alim ulama" secara tradisional masih sangat dihormati. ${ }^{32}$ Interaksi masyarakat dengan pesantren juga menyangkut hubungan antara warga pesantren dan warga masyarakat sekitarnya. Hubungan antara warga pesantren di satu pihak dan warga masyarakat di lain pihak meliputi berbagai aspek kehidupan. Namun demikian, yang tampaknya paling menonjol adalah hubungan yang bersifat ekonomi, warga pesantren berperan sebagai pihak pembeli.

Sedangkan, warga masyarakat berperan sebagai pihak penjual berbagai macam kebutuhan santri dan peralatan sembahyang, mengaji, sekolah sampai ke kebutuhan makan dan minum. Bahkan, warga masyarakat juga menyediakan rumah atau kamar bagi para santri yang tidak ingin tinggal di asrama yang di sediakan oleh pesantren.

Kemudian dalam hubungan yang bersifat pendidikan yang merupakan tujuan dari didirikannya pesantren tersebut, pihak warga pesantren (terutama para kyai dan para mubalighnya) berperan sebagai pemberi informasi (komunikator), baik yang bersifat agama (melalui pesantren) maupun ilmu pengetahuan umum melalui lembaga-lembaga pendidikan formal yang ada di lingkungan pesantren. Sedangkan, warga masyarakat dalam hal ini, berperan sebagai informasi (komunikasi). ${ }^{33}$

Pesantren dengan sistem dan karakter tersendiri telah menjadi bagian integral dari suatu institusi sosial masyarakat, Bahkan beberapa diantaranya muncul sebagai model gerakan alternatif bagi pemecah masalah-masalah sosial masyarakat desa. Ajaran-ajaran yang dituturkan oleh kyai telah membentuk pandangan, nilai-nilai, dan sikap hidup masyarakat.

Pesantren melakukan pemecahan masalah sosial masyarakat sekitarnya tidak dengan strategi dan teori pembangunan yang digunakan pemerintah. Gerakan pesantren dilandaskan pada amal saleh, sebagai refleksi dari penghayatan dan pemahaman keberagamaan sang kyai, pemimpimpin pesantren.

Hal ini yang membuat setiap pesantren mempunyai keistemewaan sendiri dalam melakukan kiprahnya, yang diperanani oleh figur kyai, serta lingkungan sosial pada suatu ruang dan waktu tertentu. Namun, ada satu hal yang sama yang melandasi gerak tersebut, yaitu berangkat dari sikap dan keyakinan agama, serta orientasi pada masyarakat. Sebagai kelompok elit

\footnotetext{
${ }^{31}$ M. Hasyim, Affan, Menggagas Pesantren Masa Depan, (Yogyakarta: CV. Qalam, 2003), 52.

32 Suismanto, Menelusuri Jejak Pesantren, (Yogyakarta: Alief Press, 2004), 73.

${ }^{33}$ Galba, Sindu, Pesantren sebagai Wadah Komunikasi, (Jakarta: Depdikbud dan Rineka Cipta, 1995), 65.
} 
Kelurahan-baik dari struktur sosial ekonomi, maupun politik-kyai memiliki peranan dan kharisma yang kuat.

Dari stuktur ekonomi, kehidupan kyai sangat berkecukupan. Oleh karena itu, mereka tidak disibukan dengan persoalan nafkah. Perhatiannya tercurah pada fungsinya sebagai pemimpin, Da'i, dan pengajar.

Untuk itu, para kyai merasa perlu memahami kehidupan politik yang sedang berkembang, dengan "kearifannya" mereka mengambil sikap. Tanpa dipaksakan sikap tersebut akan diikuti oleh jama'ahnya, dan ini yang membuat kyai mempunyai posisi kuat baik ditingkat lokal maupun nasional-dalam pengambilan keputusan politik. ${ }^{34}$

\section{E. PENUTUP}

Akar historis-kultural pesantren tidak terlepas dari masuk dan berkembangannya Islam di Indonesia yang bercorak sufistik atau mistik. Dalam pergumulannya, pesantren banyak menyerap budaya masyarakat jawa. Sejak awal kelahirannya, pesantren tumbuh, berkembang, dan tersebar diberbagai wilayah di indonesia. Keberadaan pesantren sebagai lembaga keislaman yang sangat kental dengan karakteristik Indonesia ini memiliki nilai-nilai strategis dalam pengembangan masyarakat Indonesia. Dan dalm perkembangannya pesantren terbagi menjadi dua yakni pesanten salaf dan pesantren modern. Tetapi dari dua bentuk itu, dengan keunikannya masing-masing, memiliki esensi yang sama, yakni mampu menciptakan manusia dengan karakter yang unggul.

Pesantren memiliki peranan penting dalam menjaga ekosistem kelestarian budaya Indonesia dan islam khusunya, meskipun banyak orang yang mengkritisi terhadap pesantren terkait dengan metode, system, manajemen dan lain sebagainya, tetapi terbukti bahwa yang mampu meluluskan manusia yang berkarakter (berilmu dan berakhlak) saat ini adalah pesantren, sehingga pesantren merupakan jawaban dari kebingungan masyarakat saat ini yang sering mengeluhkan terhadap tingkah pola putra-putrinya terkait dengan arus globalisasi yang sedemikian dahsyatnya.

Akhirnya dapat kita ketahui bahwa pesantren merupakan sebuah jawaban, bahwa pesantren merupakan tempat pendidikan yang tidak lekang oleh zaman, dan tidak akan hilang dengan derasnya gelombang globalisasi, karena pesantren memiliki ciri khas tersendiri yang mampu bertahan dan mampu berubah kearah yang lebih baik di tengah-tengah zaman yang serba modern.

\footnotetext{
${ }^{34}$ Madjid, Nurcholish, Bililk-Bilik Pesantren, Sebuah Potret Perjalanan, Jakarta: Paramadina, 1997, 124. 


\section{DAFTAR PUSTAKA}

A'la, Abd, Pembaruan Pesantren, Yogyakarta: Pustaka Pesantren, 2006.

Depag RI, Pola Pengembangan Pondok Pesantren, Jakarta: Ditjen Binbaga Islam, 2003.

Depag RI, Sinergi Madrasah dan Pondok Pesantren, Suatu Konsep Pengembangan Mutu Madrasah, Jakarta: Ditjen Binbaga Islam, 2004.

Depag RI, Pedoman Pembinaan Pondok Pesantren dan Madrasah Diniyah, Jakarta: Ditjen Binbga Islam, 2005.

Dhofier, Zamakhsyari, Tradisi Pesantren, Studi tentang Pandangan Hidup Kyai, Jakarta: LP3ES, 1982.

Galba, Sindu, Pesantren sebagai Wadah Komunikasi, Jakarta: Depdikbud dan Rineka Cipta, 1995.

Hasbullah, Kapita Selekta Pendidikan Islam, Jakarta: PT. Raja Grafindo Persada, 1996.

Hasbullah, Sejarah Pendidikan Islam di Indonesia, PT. Raja Grafindo Persada, 1995.

Imam Tolkhah dan Ahmad Barizi, Membuka Jendela Pendidikan, Jakarta: PT. Raja Grafindo Persada, 2004.

Madjid, Nurcholish, Bililk-Bilik Pesantren, Sebuah Potret Perjalanan, Jakarta: Paramadina, 1997.

M. Hasyim, Affan, Menggagas Pesantren Masa Depan, Yogyakarta: CV. Qalam, 2003.

Suismanto, Menelusuri Jejak Pesantren, Yogyakarta: Alief Press, 2004.

Yasmadi, Modernisasi Pesantren, Krituk Nurcholish Madjid terhadap Pendidikan Islam Tradisional, Edisi Revisi, Ciputat: Quantum Teaching, 2002. 